\title{
DEVELOPING SUSTAINABLE FOREIGN LABOUR ENTRY REQUIREMENT POLICY IN MALAYSIA
}

\author{
NAWAI NORHANA* AND HASHIM NOREHA \\ Faculty of Maritime Studies, University Malaysia Terengganu, 21030 Kuala Nerus, Terengganu, Malaysia.
}

*Corresponding author: nawaihana@yahoo.com

Submitted final draft: 31 January $2021 \quad$ Accepted: 13 February $2021 \quad$ http://doi.org/10.46754/jssm.2021.10.008

\begin{abstract}
Most countries in the world have accepted and implemented public policies aiming to promote sustainable development. The 2017 Malaysia Voluntary National Review report to the United Nations (UN) has stated that the country's quest for sustainable development can be traced back to the 1970s. Since then, numerous fiveyear-long development plans have sought to promote sustainable economic growth and equitable distribution of the resulting benefits for social transformation. However, over the decades, this has resulted in an ever-increasing dependence on both legal and illegal foreign labour. This problem has been investigated by evaluating the concept of sustainable policy in terms of its influence in Malaysia's foreign labour entry requirement, which resulted in changes for sustainable development. A qualitative research approach was used and key stakeholders were identified through purposeful sampling. Face-to-face in-depth interviews were undertaken to understand the concept of sustainable policy in Malaysia's foreign labour entry requirement and its challenges. All data obtained were analysed and interpreted through a constant comparative approach. Sustainable policymaking theory and past experience in planning suggested that various participants, commitment and knowledge are needed to formulate a sustainable policy while promoting sustainable development in foreign labour's entry requirement.
\end{abstract}

Keywords: Immigration procedures, sustainability policy, foreign labour reliance.

\section{Introduction}

The road to attaining sustainable development is fraught with challenges and obstacles. Malaysia, in its 2017 Voluntary National Review report to the United Nations (UN) on sustainable development, has stated that considerable and systematic efforts, along with various mechanisms and measures, are instituted to ensure all 17 Sustainable Development Goals (SDGs) are incorporated in a National SDG Roadmap in guiding the implementation strategies (Mukherjee, 2017). Indeed, significant achievements have been made towards reducing absolute poverty and hunger (i.e. SDGs 1 and 2); instituting different laws, policies, plans and regulations to better safeguard domestic natural resources and their sustainable utilisation (i.e. SDGs 7, 12, and 16); attaining and maintaining full employment as of 1992 (i.e. SDG 8); and, reducing income inequalities (i.e. SDG 10) (Mukherjee, 2017).

There are 4 important characteristics in sustainable development, which are connectivity and complexity, innovation, social learning and reflexivity (Zaccai,1999). These sustainable development characteristics can be achieved through systemic thinking, always open to changing conditions, applying the knowledge, being committed, international cooperation and others. In short, Sustainable Development Goals aim to achieve equitable social and economic development by using resources efficiently. Most of the Sustainable Development Hoals have been promoted through the planning of sustainable policies. Sustainable policies are well-planned policies with various programmes to accommodate Sustainable Development Goals. Therefore, it must be noted that the attainment of these achievements and future aspirations are dependent on numerous factors, one of which is sustained economic growth and its reliance on foreign labour.

According to Brundtland's definition, sustainable policies must satisfy certain characteristics, such as normative, subjectivity, ambiguity, and complexity (Brundtland Report, 
1987). In particular, the normative characteristic is about something that most people will agree with, while subjectivity refers to satisfying the needs of current and future generations. Meanwhile, ambiguity means permanently satisfying the need for the present and future (Sachs, 1999), whereas complexity describes how sustainability-related problems can no longer be addressed from only one perspective (Rotmans, 1998).

By looking at Brundtland's definition of sustainable policy, Malaysia's foreign labour policies must satisfy all four characteristics in order to be classified as a sustainable policy. Therefore, the policies on the entry requirement for foreign labour need to be supported by the people (normative), satisfy the need for current and future generations (subjectivity), ensure permanent achievement (ambiguity), and satisfy various perspectives (complexity).

The Malaysian economy experienced significant growth from 1990 to 1997 before the Asian financial crisis struck. During the crisis, the government steered the domestic economy towards its recovery and maintenance at a good level by pegging the Malaysian ringgit to the US dollar. This step successfully stimulated economic development, thus increasing the country's need for workforce in various sectors. Indirectly, it also encouraged the entry of foreign labour from different countries into Malaysia (Immigration Report, 2008). The economic sectors that lacked workforce during the country's recovery from the 1997 Asian financial crisis were the agriculture, construction, services, and manufacturing sectors (Kaur, 2012). According to the Khazanah Research Institute (2018), the number of legal foreign workers in the country increased from $1,683,000$ in 2010 to $2,235,000$ in 2017. It is estimated that the number of foreign workers in Malaysia is between 2.96 million and 3.26 million in 2019, while in 2020, since the COVID-19 pandemic, the focus has been on humanitarian efforts (ILO Report, 2020).

Furthermore, the national growth strategy has been supported by the establishment of formal guidelines for foreign labour (Ministry of Human Resources \& Institute of Labour Market Information and Analysis, 2013). Nevertheless, Malaysia has encounterd several problems concerning foreign labour, the biggest issue being their illegal entry. There are two to four million foreign workers currently in this country in which more than half of them is present illegally (Immigration Report, 2019). Most of them enter the country illegally as they cannot fulfil the entry requirements. In general, there are three types of illegal foreign labour, namely: (i) entered the country illegally; (ii) entered legally but overstayed; and (iii) cheated by agencies (Trumpbour, 2015). In Malaysia, most illegal foreign workers are those who have overstayed; they have legal documents and visas, but their overstaying renders them illegal (Ministry of Home Affairs, 2011). Foreign labour must abide by all acts, rules, and regulations before (pre) and after (post) entering the country to be legal.

Typically, entry requirements have been set up by the Immigration Department, Ministry of Home Affairs, and Ministry of Human Resources accordingly. The process starts with employers needing to inform the Labour Department in the Ministry of Human Resources regarding any job vacancy. If the vacancies cannot be fulfilled by local workers, then only they can ask for foreign workers. Entry requirements also include Immigration law, such as requirements for visa, working permit, passport, health check, and others. Furthermore, the employers have to play their part, wherein they need to abide by the Employment Act and pay a levy for these foreign workers (Immigration Department, 2019).

Reliance on foreign workers in Malaysia has been a hot topic, in which the migration system has been discussed by Wong (2006), while Mohamed, SPR and Yacob (2012) have detailed the issue of foreign workers and trade union. Meanwhile, governance and the management of foreign workers have been studied by Kassim, Too, Wong, and Abidin (2014), who found that these workers are governed by the Ministry of Human Resources, whereas the Ministry of Home Affairs serves as the leading policymakers. 
Moreover, impacts of such reliance towards the host country have been discussed by Athukorala and Devadason (2012), which include higher remittance, increased crime rate, health issues, such as Hepatitis B, productivity issues, and increased local unemployment rate. Such reliance on foreign workers brings out more negative than positive impacts, thus pushing the government to minimise the dependence.

To date, the sustainability of foreign worker entry requirements is surprisingly less extensively studied. Therefore, this study aims to examine foreign worker entry requirement policies that have been implemented in Malaysia and present its findings regarding the challenges to the attainment of Sustainable Development Goals. This paper also puts forward several recommendations and ways to improve and reduce domestic reliance on foreign workers. The findings of this study will contribute to sustainable foreign worker policies and reduce illegal foreign worker entry into Malaysia.

\section{Methodology}

The preliminary research utilised data collected from relevant websites, official government publications, and field experts. This study adopted the purposive sampling method to ensure that only respondents with the required experience for entry requirement policies were selected. In-depth interviews were conducted with eight key stakeholders, comprising of policymakers, policy implementers, policy check and balances, and policy impressed. There are representatives for each category. Entry requirement policies were mostly drawn up by the Immigration Department and have been implemented by the department itself, the Border Security Department, labour department, MMEA and the Immigrant Secretariat. ILMIA acts as check and balance since it is a department that conduct labour studies. Both employers and migrant workers are included as the policy impressed. Thus, the participants chosen were fit to answer on foreign worker entry requirement policies that have been implemented and their challenges.

The interviews were conducted over a period of three months spanning from November 2019 to January 2020. The in-depth interviews conducted consisted of semi-structured questions based on the main objective of the study, which was to identify the challenges of managing entry requirement policies for foreign labour. This study also followed the protocol for conducting interviews, including peer check, member check, and triangulation, to ensure trustworthiness of the data. The interview participants are shown in Table 1 below.

Qualitative content analysis was performed, comprising several phases. The first phase involved identifying elements to be coded and the formulation of research themes., The second phase comprised a comparison between the primary and secondary data to pinpoint any relevant themes and patterns. A coding scheme

Table 1: List of participants

\begin{tabular}{llc}
\hline \multicolumn{1}{c}{ Stakeholders } & \multicolumn{1}{c}{ Participant } & Sample \\
\hline Policymakers & Immigration Affairs & 1 \\
& Ministry of Human Resources (Labour Department) & 1 \\
\hline Policy Implementers & Border Security Department & 1 \\
& Sekretariat Immigrant Service (SKI) & 1 \\
& Malaysia Maritime Enforcement Agency & 1 \\
\hline Policy Check and Balance & Institute Labour Market Information and Analysis (ILMIA) & 1 \\
\hline Policy Impressed & Malaysian Employers Federation & 1 \\
& Malaysian Trade Union Congress (MTUC) Migrant Centre & 1 \\
\hline
\end{tabular}


was next formulated, checked, and rechecked for consistency in the third phase. Following this, data coded were interpreted in line with the research objectives. Accordingly, the data were analysed and interpreted via the constant comparative approach, which allowed more categories and themes to be formulated in answering the main study objectives.

\section{Findings}

\section{Foreign Worker's Entry Requirement Policies Implemented in Malaysia}

There are two departments and one act that serve to regulate the entry of foreign labour. In particular, the departments controlling the supply of legal foreign labour to suit the market demand are the One-Stop Labour Approval Centre and the Institute of Labour Market Information and Analysis (ILMIA). Meanwhile, the act that controls the entry of foreign labour is the Immigration Act, last amended in 2002.

Under the One-Stop Labour Approval Centre framework, the quota of foreign workers for each industry is determined by the relevant authorities. Nevertheless, there are no clear procedural guidelines to calculate this quota. To this end, both the authorities and industry representatives have claimed that they should be in charge of estimating the quota while taking into account of the views of key stakeholders (Abella, 2006; Martin, 2003).

Acknowledging the inadequacy of information on the need for foreign workers, several initiatives have been proposed in the New Economic Model (2010-2020) to gather more data on the labour market. One major initiative under the New Economic Model was the establishment of ILMIA in 2012, which was tasked with carrying out labour market studies and projections, including estimating the supply and demand of labour according to occupation and sector. This shows that the establishment of ILMIA is a meaningful step towards developing a more evidence-based policy (Naâ, 2014).

\section{Pre-entry}

The pre-entry requirement must be fulfilled by foreign workers before arriving in Malaysia so that they can legally enter the country. Therefore, every foreigner wanting to enter the country to work must understand all rules and regulations pertaining to their pre-entry requirements. There are three important factors concerning these requirements, namely prohibited immigrants, recruitment terms, and application before entry (Immigration Report, 2011).

Firstly, the Prohibited Immigrants in Part II of the Immigration Act has clearly stated which immigrants are prohibited from entering Malaysia. As listed under Section 55 of the Immigration Act, several categories of immigrants will be denied entry into the country. Among them are those without a valid pass and those unable to prove that they have definite employment awaiting them (Kaur, 2012). The third group consists of those who are suffering from mental disorders or contagious diseases, followed by immigrants refusing to submit to a medical examination, and, lastly, those convicted in any country or known as a prostitute, vagrant or habitual beggar (Immigration Report, 2008).

Regarding the recruitment terms, the employers must first obtain their foreign labour quota from the Ministry of Home Affairs. Besides, they are required to notify in advance regarding any vacancy to the Manpower Department, Ministry of Human Resources, whereby it is recommended for them to consider hiring local workers before employing legal foreign labour. This is to ensure local job seekers registered with Jobs Malaysia can fill in the vacancies first and be prioritised in the labour market.

Furthermore, foreign workers are only permitted to work in certain sectors. Only six employment sectors can recruit foreign workers, which consist of five formal and one informal sector, collectively. These sectors are the construction, manufacturing, services, plantation, and agriculture, and the domestic helper sectprs. In 2018, the services sector had the most foreign workers at 802,000 
registered individuals, while the agriculture sector was catching up with 611,000 workers. This is followed by the manufacturing and construction sectors with 515,000 and 296,000 foreign workers, respectively. The last sector is the plantation sector, with only 12,000 foreign workers (Khazanah Research Institute, 2018). Meanwhile, 15 countries are currently supplying foreign workers to Malaysia, namely Bangladesh, Indonesia, Nepal, Myanmar, India, Vietnam, Philippines (i.e. males only), Pakistan, Thailand, Cambodia, Sri Lanka, Laos, Turkmenistan, Uzbekistan, and Kazakhstan (Immigration Department, 2019). Additionally, workers from Bangladesh are not allowed to work in the agricultural sector.

Moreover, the eligibility criteria for foreign workers include an age limit of not less than 18 years and not more than 45 years at the time of application (Kaur, 2012). The allowed payroll period is five years plus five years for the five formal sectors. Meanwhile, the informal domestic helper sector has no specified period of employment, whereby any applicants satisfying the recruitment agency's requirement will be considered and approved. The job is given in accordance with the conditions and criteria established by the regulatory agencies. Other than that, foreign workers must acquire a Certified PASS for Immigration Security Clearance (ISC) from their country and certified as healthy by approved Malaysian medical centres. Lastly, these workers must not be listed as individuals who are prohibited from entering Malaysia (Immigration Department, 2019).

The third factor is the application before entry. Employers must first obtain the ISC results at the One-Stop Labour Approval Centre and send their application to the Malaysian Immigration Department for a Visa with Reference (VDR) approval before proceeding to employ foreign labour. While waiting for the VDR approval, the foreign workers must remain in their respective countries. For the states of Sabah and Sarawak, the approval for foreign worker employment is overseen by the state government.

\section{Post-entry}

The post-entry requirements must be fulfilled by employers and their foreign workers when they arrive in Malaysia. For example, the Immigration Act states that foreign workers will be allowed to enter the country only at authorised entry points using the VDR issued by the Immigration Department. Meanwhile, their entry visa will be issued by Malaysia's Attaché Office in the workers' country of origin. Secondly, the employers must ensure that the clearance process of foreign workers at the entry points is completed within 24 hours from the time of their arrival. Next, a Visit Pass or Temporary Employment will be issued to foreign workers only after they have passed their medical examination, which must be done within 30 days. The medical examination can be performed at any medical centres registered with the Foreign Workers' Medical Examination (FOMEMA).

In Malaysia, most illegal foreign workers are those who have overstayed. As such, the most crucial factor concerning post-entry requirements based on the Immigration Act is the extension of the Temporary Employment or Visa Pass. In general, Temporary Employment is valid for a period of 12 months and employers can apply for a 3-month extension, which must be done before the Visa Pass expires. Nevertheless, any application submitted after the expiry date will be referred to the Immigration Enforcement Division for consideration.

To apply for a Visa Pass extension, the foreign workers' passport must have at least 12 months of validity left. Besides, it is compulsory for them to prepare an application letter and present the company's identification document during the application. Lastly, the foreign workers must once again undergo a medical examination and be certified as fit by an approved medical centre. These steps will help them attain the legality to work in the country (MOHA, 2018).

To control the entry of foreign labour into the country, there are two provisions under the 
Immigration Act. The first provision concerns the legal process pertaining to working in Malaysia. This provision was created to control the number of legal and illegal foreign workers. The Immigration Act states that no person other than a citizen shall enter Malaysia unless he or she possesses a valid Entry Permit lawfully issued under Section 10. If found guilty, they will be liable to be fined not more than RM 10,000 or imprisoned for a term not exceeding five years or both. Furthermore, they shall be liable to whipping of not more than six strokes.

There are many cases in which deported illegal foreign workers return and become illegal again (Neeko, 2008). Therefore, an amendment was made to the Immigration Act for the unlawful return of foreign workers following removal. In Subsection 36, under return after removal, those with an unlawful entry into Malaysia shall be found guilty. Upon conviction, the person will be liable to be fined not exceeding RM 10,000 or imprisoned for a term not exceeding five years or both. They are also liable to whipping of not more than six strokes and shall, in addition to any penalty for the offence, be removed again (International Law Book Services, 2004).

\section{Challenges to Sustainable Foreign Workers' Entry Requirement Policies}

The findings on the challenges of managing foreign labour entry requirement policies are summarised as Table 2.

Table 2: Summary of challenges

\begin{tabular}{|c|c|}
\hline Participants & Challenges \\
\hline Immigration Affairs & $\begin{array}{l}\text { - To find the equilibrium point of prioritisation between industry, human } \\
\text { rights, and local people } \\
\text { - Dilemma of doing operations for illegal foreign workers; abandoned } \\
\text { job }\end{array}$ \\
\hline $\begin{array}{l}\text { Ministry of Human Resources } \\
\text { (Labour Department) }\end{array}$ & $\begin{array}{l}\text { - Limited fund to encourage automation industry } \\
\text { - Alter effect of discouraging the employment of foreign workers - they } \\
\text { employ illegal foreign workers. }\end{array}$ \\
\hline Border Security Department & $\begin{array}{l}\text { - "Show money" cannot be fully enforced due to the lack of consensus } \\
\text { with the Tourism Department } \\
\text { - Illegal foreign workers use jetty illegally around the border }\end{array}$ \\
\hline $\begin{array}{l}\text { Secretariat Immigrant Service } \\
\text { (SKI) }\end{array}$ & $\begin{array}{l}\text { - Foreign workers have no knowledge of entry requirements } \\
\text { - The entry requirement policies have too many procedures }\end{array}$ \\
\hline $\begin{array}{l}\text { Malaysia Maritime } \\
\text { Enforcement Agency (MMEA) }\end{array}$ & $\begin{array}{l}\text { - Low levy for seaman-trafficked illegal foreign workers through seaman } \\
\text { levy as a seafarer } \\
\text { - Illegal foreign workers through the ocean border }\end{array}$ \\
\hline $\begin{array}{l}\text { Institute Labour Market } \\
\text { Information and Analysis } \\
\text { (ILMIA) }\end{array}$ & $\begin{array}{l}\text { - To find the best levy system agreed by employers and capable of } \\
\text { reducing illegal foreign workers }\end{array}$ \\
\hline $\begin{array}{l}\text { Malaysian Employers } \\
\text { Federation (MEF) }\end{array}$ & $\begin{array}{l}\text { - Punitive enforcement in employing foreign workers } \\
\text { - Too many procedures to follow in order to employ foreign workers }\end{array}$ \\
\hline $\begin{array}{l}\text { Malaysian Trade Union } \\
\text { Congress (MTUC) Migrant } \\
\text { Centre }\end{array}$ & $\begin{array}{l}\text { - Employment contract vaguely stated during entry requirement policies- } \\
\text { human rights problem }\end{array}$ \\
\hline
\end{tabular}


Most of entry requirement policies are made by the Immigration Affairs from the Ministry of Home Affairs and the Labour Department from the Ministry of Human Resources. Moreover, the Foreign Worker Management Centre, One-Stop Labour Approval Department, Border Security Agency, Malaysia Maritime Enforcement Agency, and the Immigration Department are the enforcers at the border for the post-entry requirements. ILMIA advises onentry requirement policies, such as levy, foreign worker system, and others, while the Malaysian Employers Federation (MEF) represents employers from all five sectors wanting to employ foreign workers. Accordingly, the MTUC and SKI help foreign workers regarding their human rights, employment rights, and procedure for the post-entry.

Immigration Affairs is the department that formulates policies, rules, and regulation for entry requirements, such as health check, payment of levy and others, for the Immigration Department. The biggest challenge of policu formulation for foreign worker entry requirement is finding the equilibrium point between the industry, human rights, and the local population. To aid the labour-intensive industry, the policies need to be open and ease the employment of foreign workers. However, this may bring about local population outrage due to local unemployment. If priority is placed on the local people and it becomes harder to employ foreign workers, the industry will not do well, business can barely develop, and certain people will constantly lodge complaints with the Ministry of Human Resources. Furthermore, the second challenge for Immigration is carrying out an operation on illegal foreign workers, who will be detained and their jobs thus abandoned. This will also bring a negative impact on Malaysia's development.

Accordingly, the Ministry of Human Resources (i.e. Labour Department) has highlighted the challenges of limited funds to encourage the automation industry. An industry that is labour-intensive in nature will require workforce in the "3D" sectors, namely those that are dirty, dangerous, and degrading. As local labour is not willing to work in such sectors, employers are left with no choice but to employ foreign workers whether legally and illegally. The cost of hiring foreign workers is low, even though they are not productive since most of them are semi-skilled and unskilled workers. However, to reduce dependency on foreign workers, the Ministry of Human Resources wants to encourage the use of technology in the industry. The encouragement should come with funding, but there are limited funds for this since automation is cost intensive. Meanwhile, the second challenge is the altered effect of discouraging foreign worker employment. Currently, an employer that does not abide by employment law will be denied the ability to employ foreign workers, causing them to employ illegal foreign workers. The dependency on illegal foreign workers is much worse compared with legal foreign workers since it does not uphold human rights and no data is available on these people. They may be a threat, a criminal, or virus carrier.

Next, the Border Security Department has encountered problems in the law enforcement at the border. The "show money" policy that has been done in many other countries cannot be fully enforced in Malaysia due to a lack of consensus with the Tourism Department, which thinks that the policy only discourage local tourism. Meanwhile, another challenge faced by the Border Security Department is illegal foreign worker smuggling through the border using illegal jetties. Illegal jetties built around the border cannot be destroyed as they are owned by the local people lawfully according to state land law. Therefore, the enforcement of capturing illegal foreign workers around the border becomes much more difficult.

Fourth, the Secretariat Immigrant Services have stated that its challenge arises when foreign workers have no knowledge of entry requirements. For example, most illegal foreign workers want to carry out their jobs legally by following all procedures, but they do not know how and which department they should refer 
themselves to. Besides, the entry requirement policies are rife with too many procedures, each requiring money, whereas foreign workers mostly come from poor countries. Therefore, too many procedures will also hinder them from becoming legal foreign workers.

Moreover, the Malaysia Maritime Enforcement Agency (MMEA) has acknowledged the challenge of low levy payment for seamen. Other sectors have levy payments ranging between RM640 and RM1850 (Immigration Department, 2019), whereas the levy payment for seamen is not more than RM30.00 (Marine Department, 2019). Therefore, many irresponsible people opt to traffic illegal foreign workers through the seaman levy as a seafarer, as well as their entry through the ocean borders by small and large boats.

Accordingly, ILMIA has highlighted the issue of local people helping illegal foreign workers. Here, local employers already know that their employees are illegal in nature but choose to employ them anyway since they can pay a lower salary and threaten these illegal workers to send them back or report them to the Immigration Department. The next challenge for ILMIA is finding the best levy system agreed by employers and capable of reducing the number of illegal foreign workers. Employers will favour a lower levy for foreign workers so that they can employ more foreign workers and gain more profit. However, it is better to have a higher-priced levy to prioritise local employment. Therefore, ILMIA suggests the use of the multi-tiered levy by adopting the Singapore Pricing Mechanism Levy.

Next, the Malaysian Employers Federation (MEF) has argued about the lack of punitive enforcement by the government towards employers who hire foreign workers. Employers that do not follow employment law should be punished, but they should not be denied the ability to employ foreign workers. Here, foreign worker employment and employment law punishment should be distinguished accordingly since they are two different things. Secondly, there are too many procedures in employing foreign workers. Employers typically have many other things that they need to focus on since they are businessmen first and foremost, and the government should support the industry since they are making profit and increasing Malaysia's economy.

Lastly, the Malaysian Trade Union Congress (MTUC) Migrant Centre has discussed the challenges, wherein employment contracts are vaguely stated in the entry requirement policies. Legal foreign workers in Malaysia are all requested by the employer while the employment contracts are vague, thus resulting in some foreign workers being cheated. These contracts vaguely state that they will be working in the services sectors, and they end up working as sex workers upon arrival. This also triggers human rights issues.

\section{Discussion}

Foreign worker entry requirement policies must satisfy sustainable policy characteristics, namely, subjectivity, normative, complexity and ambiguity. A sustainable entry requirement policy is needed to achieve sustainable development in Malaysia. Sustainable development has five characteristics, which are connectivity and complexity, innovativity, social learning, reflexivity and equitable.

The foreign labour entry requirements include pre-entry and post-entry clauses and have increased security and prioritised local people. The requirement to advertise any job vacancy and prioritise local people before foreign workers satisfies the normative characteristic, wherein most of the local population agrees with the policy. It also tightens security by requiring health checks for foreign workers, while enforcing criminal listing has gained support from people who care about social security in Malaysia. Therefore, both employers and local people are happy with the policy.

Subjectivity refers to the policy's need to satisfy current and future generations. Industries in Malaysia are labour-intensive in 
Table 3: Entry requirements as sustainable policy

\begin{tabular}{|c|c|}
\hline $\begin{array}{l}\text { Sustainable Policy } \\
\text { Characteristics }\end{array}$ & Entry Requirement \\
\hline $\begin{array}{l}\text { Subjectivity - Satisfy current and } \\
\text { future needs }\end{array}$ & $\begin{array}{l}\text { - No - The policies of employing foreign labour keep on changing. } \\
\text { Sometimes they are allowed, sometimes they are freezed } \\
\text { - Employers always need more foreign labour } \\
\text { - Foreign labour are unskilled/semi-skilled, which cannot satisfy } \\
\text { future needs in terms of technology use }\end{array}$ \\
\hline $\begin{array}{l}\text { Normative - Follow normal rules } \\
\text { in society }\end{array}$ & $\begin{array}{l}\text { - Yes - It has included all the basic necessities for entry requirement } \\
\text { laws, such as security checks health checks, working pass and visa } \\
\text { requirements. } \\
\text { - Yes - Divide working permit of foreign labour according to sectors }\end{array}$ \\
\hline $\begin{array}{l}\text { Complexity - Includes various } \\
\text { perspective }\end{array}$ & $\begin{array}{l}\text { - Entry requirement include human right perspective - minimum } \\
\text { wages for foreign labour, working conditions and basic amenities } \\
\text { - Include International Labour Organisation(ILO) perspective - not } \\
\text { holding any money as guarantee to make sure foreign labour return } \\
\text { to their home country } \\
\text { - Does not include employer's perspective - Request for foreign } \\
\text { labour by employers who did not fulfill the requirements will not be } \\
\text { fulfilled } \\
\text { - Include society's perspective - Prioritise local people before foreign } \\
\text { labour }\end{array}$ \\
\hline $\begin{array}{l}\text { Ambiguity - Considered social } \\
\text { and economic factors }\end{array}$ & $\begin{array}{l}\text { - Social - Follow health check and security check, however, it will } \\
\text { reduce job opportunities for local people } \\
\text { - Economic - Foreign labour unproductive, policy does not open to } \\
\text { use of technologies, and usage of resources is not efficient }\end{array}$ \\
\hline
\end{tabular}

nature and heavily rely on foreign workers. When local workers are not interested to work in the $3 \mathrm{D}$ sectors, the industrial needs are not met. Furthermore, tightening up foreign worker entry requirements reduces the number of legal foreign workers, preventing the policy from achieving subjectivity due to their challenges. Moreover, it is a challenge for the Ministry of Human Resources to shift the current labourintensive industry to an autonomous one.

Since subjectivity cannot be achieved, the same goes to the ambiguity characteristics. It is a challenge for employers to reduce dependency on foreign workers while the government is carrying out punitive enforcement. Social factors, such as health checks and security checks, have been satisfied by the entry requirements. Even though every job opening should prioritise local people, employers still choose to employ foreign labour to increase their profit. The economic factors are not being considered carefully since foreign labour are mostly unskilled and semiskilled. Nearly $40 \%$ of the foreign workers in Malaysia have had no formal education and only $10 \%$ have tertiary education (Chia, 2011). Thus, it reduces productivity, increases more usage of resources and does not open to use of technology.

Meanwhile, complexity emphasises the various perspectives and this cannot be 
achieved by the entry requirement policies as the perspective only concerns the human rights perspective and International Labour Organisation (ILO) perspective. Entry requirements include minimum wages for foreign labour, basic amenities and other foreign labour's rights. It also includes perspective from ILO, which is not to hold any deposit money from foreign labour as has been practised by United
Kingdom and a few other countries. However, it does not include employers' perspective of separating the foreign labour application and employment law. Society's perspective is less considered compared with the perspective of economy needs since the government constantly inks deal with neighbouring country for foreign labour supply.

Table 4: Entry requirement in sustainable development

\begin{tabular}{|c|c|}
\hline Sustainable Development Characteristics & Entry Requirement \\
\hline $\begin{array}{l}\text { Connectivity and complexity } \\
\text { - System thinking }\end{array}$ & $\begin{array}{l}\text { - One-Stop centre to collect all requests on foreign labour } \\
\text { - No encouragement to change to the automotive industry }\end{array}$ \\
\hline $\begin{array}{l}\text { - Future orientation } \\
\text { - International }\end{array}$ & $\begin{array}{l}\text { - Follow recommendations from ILO, and always be up to } \\
\text { date with the regional discussions regarding foreign labour }\end{array}$ \\
\hline $\begin{array}{l}\text { - Multi, inter-transdisciplinary } \\
\text { Innovativity } \\
\text { - Open to changing conditions }\end{array}$ & $\begin{array}{l}\text { - Sometimes follow the recommendations from ILMIA } \\
\text { - Yes, health checks for new viruses and other diseases. } \\
\text { Security checks to reduce criminal cases }\end{array}$ \\
\hline $\begin{array}{l}\text { - Open to new solutions } \\
\text { - Function orientation }\end{array}$ & $\begin{array}{l}\text { - Yes, Bangladesh labour are not allowed to work in } \\
\text { plantations since they are not familiar with the industry } \\
\text { - Yes, Indonesian domestic helpers are employed to reduce } \\
\text { the language barrier }\end{array}$ \\
\hline $\begin{array}{l}\text { Social Learning } \\
\text { - Application of knowledge }\end{array}$ & $\begin{array}{l}\text { - Yes, uses IT system to ease the procedure of entry foreign } \\
\text { labour }\end{array}$ \\
\hline - Multile methods & - No, "show money" is still not being applied \\
\hline - Real-life situation & $\begin{array}{l}\text { - No, still focuses on intelligence, Immigration raids on } \\
\text { illegals, detention, deportation and legalisation }\end{array}$ \\
\hline - Cooperation & $\begin{array}{l}\text { - Yes, Immigration Department never conducts raids on all } \\
\text { sectors to avoid disrupting jobs }\end{array}$ \\
\hline & $\begin{array}{l}\text { - Always evaluate and do operations to fight illegals. } \\
\text { - MOHA and MOHR collaborate in policymaking for } \\
\text { foreign labour }\end{array}$ \\
\hline
\end{tabular}


Reflexivity

- Learning to learn

- Responsibility

- Value-driven

- Critical thinking

- Awareness of information

Equitable

- Equity between social and economic development

- Efficiency in resources

- Keep the environment safe
- Yes, there are provisions for government research bodies, like ILMIA,MIMA, and government research grant to conduct research on certain issues

- During the COVID19 pandemic, Malaysia takes care of the health and welfare of foreign labour

- No, entry requirement is more to reactive policy

- Yes, entry requirements include ATIPSOM to handle human smuggling

- Country - Loss because of increase in remittance, higher brain drain, reduced efficiency and reduced job opportunity for local people

- Profit-oriented people who uses foreign labour would not pay money to take care of the environment. Dirty towns around foreign labour area, such as the Selayang Market
There are five important characteristics in sustainable development, which are connectivity and complexity, innovation, social learning, reflexivity, and equitable. The connectivity and complexity characteristics emphasise systemic thinking. The entry requirements in Malaysia have a stable application system for foreign labour, immigration system and even systems for human resources. Malaysia is always active in participating in regional discussions on foreign labour, such as the ASEAN Forum on Migrant Labour (AFML) and the ASEAN Consensus on the Protection and Promotion of the Rights of Migrant Labour. However, there are no future orientation since the entry requirements in Malaysia is still focusing on employing unskilled and semi-skilled labour. Australia also employs semi-skilled labour, but they include English tests to reduce language barrier and increase productivity.

The next characteristic is innovation. The entry requirement policies are always open to changing conditions. They include health and security checks following the spread of viruses, such as Hepatitis B from foreign workers who did not get vaccinated in their home country. It is also open to new solutions. Bangladesh workers are not allowed to work in plantations since they are not familiar with them. Therefore, most of
Bangladeshi workers would work in the services, manufacturing and construction sectors. This has satisfied the function orientation, where Indonesian domestic workers are preferred since they have a similar language that is easily understood by locals.

Sustainable development needs to have social learning characteristics. The application of knowledge is important in this characteristic. However, the entry requirements seem to have problem in applying knowledge if consensus with other departments are not achieved, such as on the "show money" policy. Even though this policy has been widely used by other countries, since the Tourism Department strongly disagrees with this policy, thus, the entry requirements could not apply them. The Immigration Department always practises real-life situations for the entry requirement policy. This includes inspections at the border, and even raids on certain sectors. They implement these policies step by step. The levy payment for foreign labour has been calculated carefully according to the real-life situations and employers' ability. In social learning, commitment is also one of the important elements. Commitment can be seen through the evaluation of every policy, and operations to combat illegal foreign labour. Next is cooperation. The Ministry of Home Affairs 
(MOHA) and Ministry of Human Resources (MOHR) are always cooperating in making policies for foreign labour by exchanging thoughts and expertise. Human resources expert focuses on labour, while the Ministry of Home Affairs look after security. They also engage with related departments before any policy is formulated.

Reflexivity is the other characteristics of sustainable development, which include learning to learn, hold responsibility, critical thinking and also being aware of information. We can see that entry requirements are studied through research bodies and these studies funded by government research grants. Every decision-making process would undergo a thorough research first. The entry requirements are always up to date with other countries' entry requirements so that their weaknesses can be identified and addressed. Responsibility could be seen during the COVID-19 pandemic, where Malaysia cared for the health and welfare of foreign labour, regardless of whether they were illegal or legal. However, Malaysia still lack critical thinking since the entry requirement policies are reactive policy. The ATIPSOM policy is proof of the awareness of information for entry requirements since it is aware about the human smuggling among foreign labour and refugees. The Malaysia Maritime Enforcement Agency (MMEA) showed that they hold responsibility by training regularly to increase coordination with other agencies. Therefore, good governance will allow knowledge flow, hence increasing the understanding and cooperation between stakeholders. This has been agreed by Abdullah, Ahmad, and Ariff (2018).

In general, we can say that the Sustainable Development Goals are creating a better world with a better environment, and a balance between social and economic aspects, and efficiency in resources usage. As Malaysia moves towards the Industrial Revolution 4.0, entry requirements prioritising unskilled and semi-skilled foreign labour are not wise. Other than being unproductive, they are not efficient in using resources, increase remittance and brain drain. A total of RM32.1 billion have been remitted by foreign labor to varies countries (MOF, 2014). About 100,000 Malaysians are migrating out of the country every year and the number has continued to increase.

\section{Recommendations}

This study provides recommendations in the formulation of sustainable policies and recommendations to reduce dependency on foreign labour in achieving sustainable development.

To formulate sustainable entry requirement policies, the government needs to shift employment focus from unskilled to skilled foreign labour. It can include examinations or tests before foreign workers can receive a working permit. The examinations can include certain qualifications and can reduce language barrier. Secondly, the government needs to stick to the quota of foreign labour that has been calculated by the One-Stop Labour Approval centre, while reducing agreements with neighbouring countries to keep employing foreign labour. Thirdly, the government needs to support local employment by increasing their productivity, providing better wages and fringe benefits. Through this way, Malaysia can sustain longer with local human resources, reduce brain drain and remittance. Fourth, the entry requirements need to include various perspectives, such as related stakeholders, the International Labour Organisation and human rights. Fifth, reduce any unnecessary entry requirement procedures for employers and foreign workers alike. The presence of red tape or too many procedures will make them opt for the illegal way, which is easier.

To reduce dependency on foreign workers, it is recommended for Malaysia to create an unconducive environment for illegal foreign workers. The Ministry of Human Resources should encourage automation in the industry, even with limited funds, by offering tax exemptions or undertaking collaborations with developed countries in the production of 
technology. Next, it is recommended for the Border Security Department to collaborate with the Tourism Department and Immigration Department to fully enforce the "show money" policy. Enforcement that is parallel to the studies must be implemented, such as using one single system and one single governance system in governing foreign labour. There should be a systematic effort exerted parallel to the high or low demands for labour in every sector. Lastly, the laws should be amended, and Malaysia can refer to other countries, such as Japan, which has a very strict anti-immigration policy, known as the Nikkei Law, and uses a point-based system. Similarly, Dubai prohibits foreign workers from joining labour unions. As such, the entry requirement policies should always be evaluated.

\section{Conclusion}

The main goals of the current study were to examine foreign labour entry requirement policies in Malaysia and present findings on challenges to sustainable policy and sustainable development. Foreign labour is generally managed by the Ministry of Home Affairs, Ministry of Human Resources, and nongovernmental agencies. Their entry requirement policies include immigration procedures and employer procedures alike. In particular, the pre-entry requirements concern the processes and actions that need to be done before coming to Malaysia, whereas post-entry requirements are the process during worker entry.

The current study unveiled the tip of the iceberg regarding the challenges pf the entry requirements in becoming a sustainable policy. In view of the second question, aforementioned, the common challenges faced in the governance of foreign labour with regards to entry requirement policies are funds, knowledge, cooperation from various stakeholders, and policy dilemma. Few characteristics of sustainable policy has been satisfied by entry requirement policies, and some are not.
A sustainable entry requirement policy could assist sustainable development in Malaysia through reducing illegal foreign workers, improve productivity, society health and political stability, and reduce brain drain, security problems, as well as remittance. Since more than half of the foreign workers in Malaysia are illegal, sustainable entry requirements could reduce the number of illegal foreign workers not just through deporting and detaining them. Productivity of foreign workers is low since they are low-skilled and unskilled workers. Sustainable entry requirements allow foreign workers to increase their productivity through language examinations and basic trainings. Health and security screenings could be tightened in sustainable entry requirements to improve society health by reducing TB and Hepatitis risk. Lower number of foreign workers in Malaysia would eventually reduce remittance economically, while political stability could be achieved through better relations with neighbouring countries.

The dependency on foreign labour in Malaysia is a very alarming issue. The best way to prevent thus is through sustainable entry requirement policies, which must be precise, clear, and parallel to the current needs. This may be achieved by applying the aforementioned recommendations in the management and policies, such as improve skills of and increase wages for local labour, stick to the quota given by One-Stop Labour Approval Centre, creating an unconducive climate for foreign labour and encouraging automation in the industry. If the debate is to be moved forward, a better understanding of policy and governance of foreign labour needs to be developed.

\section{Acknowledgements}

The author would like to acknowledge the funding given by Universiti Malaysia Terengganu PGR Grant, project code: 55193/8. 


\section{References}

Abdullah, T., Ahmad, N., \& Ariff, A. (2018). Combating corruption for sustainable public service in Malaysia: Smart Governance Matrix and Corruption Risk Assessment. Journal of Sustainability Science and Management, Special Issue(4).

Abella, M. (2006, June). Policies and best practices for management of temporary migration. In International Symposium on International Migration and Development (Vol. 3). Turin: United Nations Secretariat.

Athukorala, P. C., \& Devadason, E. S. (2012). The impact of foreign labor on host country wages: The experience of a southern host, Malaysia. World Development, 40(8), 14971510.

Chia, F. C. (2011), Economic fluctuations and productivity in the Malaysia Construction sector. PhD thesis, Queensland University of Technology.

Immigration Department. (2019). Syarat-syarat pengambilan pekerja asing, Perkhidmatan Utama. www.imi.gov.my.

Immigration Report. (2008). Immigration Annual Report Official Documents 20082009. Ministry of Home Affairs Malaysia National Publication.

Immigration Report. (2019). Immigration Report Official Documents 2019. Ministry of Home Affairs Malaysia National Publication.

Immigration Report. (2011). Immigration Report Official Documents 2010-2011. Ministry of Home Affairs Malaysia National Publication.

International Labor Organization Report. (2020). Triangle in ASEAN Quarterly Briefing Note (Malaysia January - June 2020). Bangkok: Document of the World Bank.

International Law Book Services. (2004). Immigration Act (1959), Regulations and Orders, Passport Act (1966) as at $4^{\text {th }}$ August
2004. International Law Book Service Publication.

International Migration Outlook (2012), Foreign workers from selected countries by destination. OECD ilibrary publications.

Kassim, A., Too, T., Wong, S. C., \& Abidin, M. Z. (2014). The management of foreign workers in Malaysia: Institutions and governance regime. Managing International Migration for Development in East Asia, 241.

Kaur, A. (2012). Labour Brokers in migration: Understanding historical and ccontemporary transnational migration regimes in Malaya/ Malaysia. International Review of Social History,57(S20), 225-252. doi:10.1017/ s0020859012000478

Khazanah Research Instittute (2018). Different Realities: State of households. Khazanah Research Institute Publications.

Martin, P. (2003). Managing labor migration: Temporary worker programs for the $21^{\text {st }}$ century. Institute for Labour Studies. Geneva: ILO.

Marine Department (MARDEP). website: www. mardep.gov.my, last accessed in December 2019.

Ministry of Finance Malaysia. (2014). Economic Report. Official Documents. Kuala Lumpur: National Publication, 2014.

Ministry of Home Affairs Malaysia. (2011), Official Documents. Kuala Lumpur: National Publication.

Ministry of Home Affairs Malaysia. (2018). Official Documents. Kuala Lumpur: National Publication.

Ministry of Human Resources of Malaysia \& ILMIA. (2013). Immigration in Malaysia: Assesment of its economic effects and a review of the policy and system. Document of the World Bank. 1-273.

Mohamed, R. K. M. H., SPR, C. R., \& Yacob, P. (2012). The impact of employment of foreign workers: Local employability and 
Trade Union roles in Malaysia. International Journal of Academic Research in Business and Social Sciences, 2(10), 530.

Mukherjee, J. S. (2017). The Millennium Development Goals and Sustainable Development Goals. Oxford Scholarship Online. doi:10.1093/oso/9780190662455. 003.0003

Naâ, M. (2014). The dilemma of managing foreign workers in Malaysia: Opportunities and challenges. Global Journal of HumanSocial Science Research.

Neeko, R. (2008). Arrest, detention and prosecution of migrant workers in developing comprehensive policy framework for migrant labor. Jakata: International Labor Organization.

Rotmans, J. (1998). Methods for IA: The challenges and opportunities ahead. Environmental Modeling \& Assessment, 3(3), 155-179.

Sachs, W. (1999). Sustainable development and the crisis of nature: On the political anatomy of an oxymoron. Living with Nature, 23(1), $23-42$.
Trumpbour, J. (2015). "What part of 'Illegal' don't you understand?": Undocumented: How immigration became illegal. New Labor Forum, 24(3), 109-112. doi:10.1177/ 1095796015597000

World Commission on Environment and Development, \& Brundtland, G. H. (1987). Presentation of the Report of the World Commission on Environment and Development to the Commission of the European Communities, the EC and EFTA Countries on 5 May 1987, Brussels. World Commission on Environment and Development.

Wong, D. (2006). The recruitment of foreign labour in Malaysia: From migration system to guest worker regime. In Mobility, labour migration and border controls in Asia (pp. 213-227). London: Palgrave Macmillan.

Zaccai, E. (1999). Sustainable development: Characteristics and interpretations. Geographica Helvetica, 54(2), 73-80. 